\title{
CONTROLLING THE MINISTERS
}

\author{
RAYMOND D. SCHACHTER*
}

\begin{abstract}
The author examines the subject of assignment of powers to Ministers and administrative boards and the subsequent erosion of individual rights of redress against their decisions. He presents a review of Canadian and British decisions dealing with problems of limiting the bases for the use of these powers. The effectiveness of court action as a device for controlling executive power is left as a question requiring further discussion.
\end{abstract}

\section{INTRODUCTION}

In recent times governments in the various provinces of Canada, the federal government and other governments in the western world have exhibited a strong tendency to pass legislation which delegates to Ministers of the government, administrative heads of government and administration boards substantive and sweeping powers. The reasons for this trend are many and appear to be related to the complexity of present day society which causes elected officials to place much reliance upon administrative boards. The members of these boards are expected to develop the expertise to adjudicate technical issues. If the technical knowledge is coupled with good judgment and a bona fide application of statutory powers, the ultimate decision reached by the board should be as equitable as realistically possible in an imperfect society. ${ }^{1}$ This article is concerned with sweeping powers granted to the Ministers, or to the Lieutenant-Governor in Council to legislate or to regulate, rather than with administrative boards which have been the subject of exhaustive legal research. However, the same principles which require a board to act within its legislative powers have recently been applied to Ministers and to the Lieutenant-Governor in Council.

Notwithstanding this application, individual rights have been eroded as a result of this trend to delegate to Ministers and to the LieutenantGovernor in Council. Contemporary examples include the loss of individual rights, the right to utilize property and the right to carry on businesses.

Recently the Court of Appeal of Alberta was called upon to consider such a case and the judgment rendered by that court serves to illustrate modern judicial reasoning in this area of Canadian jurisprudence. The case, Heppner v. The Minister of the Environment et al. ${ }^{2}$ arose out of the following circumstances. In 1971 the Department of the Environment Act $^{3}$ was passed by the legislature of Alberta. This Act provided for the establishment of restricted development areas (hereinafter called "R.D.A.'s") for purposes which may be paraphrased as the protection of the environment and the Act was administered by the Minister of the

\footnotetext{
- Harrister and Solicitor, Witten, l'ekuraky \& Vogel, Memlı!r of the l,aw Society of Alberta, Member of the Law Socioty of Upper Canada.

I. P. W. Hokg hus commented upon the necessity for administrativa boards, their qualificntions, and review by the courts in his article entitled, Judicial Reviow: How Murh Do W. Need? (1974) 20 Morill I, aw Journal 157 See' also W. H. Angun, The Individual and the Aureaucrocy: Jtudicial Keview-Do We Need It? (1974) 20 M(Gill Jaw Juurnal 177 .

2. $(1977)$ 6 A.K. 154

i. S.A. 1971, c. 24 , as amended in respecte relevant to this artiele by S.A. 1975, c. $51,8.8$.
} 
Environment. ${ }^{4}$ Pursuant to the Act, the RDA's were to be established by orders-in-council. 'The Act contained no requirement that the affected members of the public be given notice prior to the passing of such ordersin-council, an opportunity to be heard or any other fundamental rights, despite the fact that land within an RDA could not be developed in any manner whatsoever without the prior approval of the Minister of the Environment. As counsel for Mr. Heppner so aptly stated, a person owning land in an RDA could not dig a well or even build an outhouse without the Minister's approval. On the face of it, there did not appear to be an appeal procedure whatsoever for an individual whose rights were affected by such an order-in-council, and traditionally, Canadian jurisprudence has not left the door widely ajar for such disputes. ${ }^{5}$

Orders-in-council were, in fact, passed establishing various RDA's and it becaine apparent soon after the passing of the first order-in-council that government policy was directed towards creating a narrow strip of land about cone-half mile in width surrounding the entire City of Edmonton as a so-called green belt. Heppner's land was located on the south side of the city within the south Edmonton RDA. The south Edmonton RDA was created by an order-in-council promulgated on September 29, 1976 and upon its creation, the RDA's completely encircled the city. The titles of land in this RDA were encumbered by caveats in January, 1977.

However, when this final RDA was promulgated, the assistant deputy minister of the Department of the Environment sent a letter to all landowners in the south Edmonton RDA advising that the passage "by Cabinet" of the RDA was "for the purposes of establishing a transportation and utility corridor." The letter further advised that a public meeting had been arranged by Department officials to explain the restricted development: area and answer general questions about the nature and intent of the area. There was no indication in this correspondence that any landowner could take action or make complaints which would in any way alter the order-in-council or release land from restrictions imposed by creation of the RDA.

4. Section 2 of the Act sets forth the purposes of the Act:

For the purposes of this Act, the following are matters pertaining to the environment:

(b) the prevention and control of pollution of natural resources;

(c) the prevention of noise and the control of noise levels resulting from commercial or industrial operations in so far as they affect the environment in the vicinity of those operations;

(d) economic factors that directly or indirectly affect the ability of persons to carry out measures that relate to the matters referred to in Clauses (a), (b) and (c);

(e) any operations or activities

(i) that adversely affect or are likely to adversely affect the quality or quantity of any natura resource, or

(ii) that destroy, dinturb, pollute is alter or make use of a natural resource or are likely to do $\mathrm{sv}$; (f) the preservation of natural resources for their aesthetic value;

(k) Iaws in force in Albertu that relate to or directly or indirectly affect the ecology of the environınent or natural resources.

Regulatiors ure authorized by Section 1501) of the Act:

15.1) The lieutenantfovernur in Council may by rexulation establish any part or parts of Allserta as a 'Restricted Development Area' ar a 'Wuter Conservation A rea' (in this section called 'the A rea'), upon the repart of the Minister thut the estahlishment of the Area is necessary in the public interest to co-cordinate and rexulate the development ind use of the A rea for the purpose of

(a) preventing. controlling, alleviating or stopping the destruction, damage or pollution of any nutural resources in or adjacent to the $A$ ret, or

(b) protecting a watershed in or adjacent to the A rea, or

(c) retaining the environment of the Area in a natural gtate or in a state suitable for recreation or the propugation of plant or animul life, or

(d) preventing the deterioration of the quality of the environment of the Area by reason of the development or use of land in the arta incompatible with the preservation of that environment.

5. Infra, text at n. 22 . 
Many people who owned land in the various RDA's established around the city were exceedingly concerned about the creation of these RDA's because of the effective sterilization of land which was ripe, in many cases, for industrial and residential development. Thus the value of the land in these RDA's was drastically reduced. In fact, the value of the land is now very difficult to determine because of the dearth of the land sales in the various RDA's since the creation of these RDA's. No challenge of any real consequence was made to the south Edmonton or other RDA's prior to the Heppner application. The application arose indirectly as a result of an application by Dome Petroleum Limited to the Energy Resources Conservation Board (the board having jurisdiction to grant pipeline permits) to build a pipeline running easterly along the entire south Edmonton RDA, then turning north and running along the east Edmonton RDA. As there was an existing pipeline right-of-way running diagonally through the city short-cutting the RDA route by several miles, it appeared rather strange that Dome would choose a route running through the RDA. A number of affected landowners sought legal assistance and after some investigation the above-mentioned correspondence from the assistant deputy minister surfaced along with two other relevant facts.

Firstly, Dome's original application had been made prior to the orderin-council establishing the south Edmonton RDA. This original application showed the pipeline as running along the existing right-of-way, and not through the RDA. Secondly, it became clear from correspondence from the Minister's office to the Energy Resources Conservation Board that the Minister of the Environment, pursuant to his powers under the Department of the Environment Act and the order-in-council establishing the RDA, would authorize the pipeline provided the route ran along the south Edmonton RDA and then turned north along the east Edmonton RDA. Thus, the Minister of the Environment effectively vetoed any pipeline not built along the route that he directed.

An application brought by a number of landowners, including $\mathrm{Mr}$. Heppner, before the Supreme Court of Alberta to impugn the order-incouncil on the basis that it did not fall within the scope authorized by the. Act was made returnable the day before the Energy Resources Conservation Board was scheduled to hear Dome's application. The application requested, inter alia, a declaration that the south Edmonton RDA be declared invalid. Oral judgment rendered by Chief Justice of the Supreme Court of Alberta, J. V. H. Milvain, on the date of the return of the application ruled against Heppner. ${ }^{6}$ The unfortunate sequence of subsequent events can lead only to the conclusion that it is becoming untenable for any individual to fight the provincial government and a well established pipeline company providing services which appear essential to the economy of the province, notwithstanding what we would like to consider the fundamental legal rights of such individual.

The Energy Resources Conservation Board decided to proceed with Dome's application notwithstanding the fact that the objectors advised the Board that the validity of the south Edmonton RDA was in doubt, and that an appeal would be launched forthwith to the Court of Appeal from the decision of the Chief Justice. The Board gave its decision in two

1j. We alwo Famous Plavers Itd. if al. v. The Energy Resuurces Consertation Board (Court of Appeal of Alberta, Siptember, 1976), an unrepurted deciaion of Clement J.A. referred to in the Heppner case, supra, n. 2 at 169; see Romaniuk et al v. The City of Edmonton (Supreme Court of Alterta, Trial Division, June 28, 1977), an unrepreded deciaion of Chief el untice Milvain in which the principles of compentation are contidered. 
stages. The first part of the decision approved most of the pipeline; reserving judgment on the portion of the pipeline passing through the City of Edmonton. The remainder of the decision, rendered on June 21, 1977, granted a permit to Dome to complete the pipeline through the south Edmonton RDA as required by the Minister. By that time, the Heppiner appeal had been heard by the Court of Appeal but no decision had yet been rendered.

Meanwhile, the landowners realized that once Dome had constructed its pipeline through the RDA, a successful decision in the Court of Appeal would not likely lead to the ultimate removal of the pipeline. As well, from a tactical point of view, if Dome were enjoined from building the pipeline, Dome would undoubtedly attempt to apply what pressure it could to arrive at a quick settlement of the matter so that the pipeline could be completed. Further to complicate the matter, the decision of the Energy Resovirces Conservation Board reached some of the landowners, including Hepplner, after the appeal period for an appeal to the Court of Appeal from the decision of that Board had expired and this Heppner and others were required to make an application to the Court of Appeal for an extension of the appeal period. Further, applications were made to the Energiy Resources Conservation Board to temporarily halt the pipeline in the south Edmonton RDA until the decision of the Court of Appeal was rendered, or untill the Court of Appeal had rendered a decision in respect of the appeal of the decision of the Energy Resources Conservation Board. ${ }^{7}$ Despite all of these efforts, the Board refused to withhold the permit beyond August 31, and on the following day Dome began work in the scuth Edmonton RDA. Substantial work had already been completed by the time the judgment of the Court of Appeal was rendered on September 16, 1977.

The decision of the Court of Appeal declared invalid the order-incouncil thus impugning the entire south Edmonton RDA. ${ }^{8}$

Heppner relied primarily on two arguments:

(i) The first argument sought to impugn the order-in-council on the promise that it was promulgated for the purpose of creating a transportation and utility corridor, a purpose not authorized by the Act, and

(ii) The second issue argued by Heppner was that the order-in-council wo.s contrary to Section 1(a) of the Alberta Bill of Rights ${ }^{9}$ which states that:

... In Alberta there exists without discrimination . . . the following human rights and fundamental freedoms. .

(a) the right of the individual to ... enjoyment of property, and the right not to be deprived thereof except by due process of law ...

The C ourt of Appeal did not deal with the provisions of the Alberta Bill of Rights because if found in favour of Heppner on the first argument. However, the Bill of Rights argument has certainly not been abandoned.

In dealing with the first issue, namely, whether the order-in-council was promulgated for a proper purpose, the Court of Appeal relied upon the

7. Theri: is provision in Energy Regources Conservation Hoard Act, S. $\Lambda .1971$, c. 30, as umended, jursuant to bection 40 for the Bourd to review, rescind, change, alter or vary any order or direction made by it. There is further provision pursuant to set:tion $\$ 2$ to appeal to the Court of A ppeal with leave within one month after the muking of the order by the Buard.

8. The decision was rendered by Lieberman J.A. for the court.

9. S.A. 1972, c. 1 . 
well-known case of Roncarelli v. Duplessis, ${ }^{10}$ citing a particular portion of that decision as follows: ${ }^{11}$

In public regulation of this sort, there is no such thing as absolute and untrammeled 'discretion' that is that action can be taken on any ground or for any reason that can be suggested to the mind of the Administrator; no legislative Act can, without express language, be taken to contemplate an unlimited arbitrary power exercisable for any purpose, however capricious or irrelevant, regardless of the nature or purpose of the statute. Fraud and corruption in the commission may not be mentioned in such statutes but they are always implied as exceptions. 'Discretion' necessarily implies good faith in discharging public duty; there is always a perspective in which a statute is intended to operate; and any clear departure from its lines or objects is just as objectionable as fraud or corruption.

It is submitted that two matters are raised by this quote. The first is that any legislative Act has limits and nothing done pursuant to the Act can go beyond those limits. The second is that if an Act allows discretion, such discretion must be exercised properly and in good faith. ${ }^{2}$

The first matter had already been determined by the Supreme Court of Canada in Hartley v. Mason ${ }^{13}$ and this case is specifically referred to in the judgment of the Court of Appeal.

The Court of Appeal also indicated, in its decision, that there is a presumption which must be overcome that subordinate legislation is within the authority conferred by the Act and that the court will not declare it invalid unless there is clear evidence to support such a finding. ${ }^{14}$

In the writer's view, the Court of Appeal relied basically on the Roncarelli case and the case of In Re Doctors Hospital and Minister of Health et al. ${ }^{15}$ The latter case is discussed in more detail below. The court determined as follow $8:{ }^{16}$

Notwithstanding the purpose expressed in the preamble to order-in-council $1062 / 76$, it is
apparent from the evidence that the main and compelling purpose in passing it was to
create a transportation and utility corridor. I have come to this conclusion in light of the
letter of the Minister of the Environment, dated December 23,1976 , Exhibit $D$, the letter
of the Assistant Deputy Minister, dated October 5,1976 , Exhibit $B$, and the other
documents before me, combined with the fact that the order-in-council was promulgated
very shortly after Dome's application for a permit to construct a pipeline and in view of
the narrow strip of land which was to comprise the RDA. The court went on to determine: ${ }^{17}$

However, the placing of a transportation and utility corridor, the expressed and as I have found motivating purpose behind the impugned subordinate legislation, within the RDA can have nothing but a detrimental effect to the RDA or indeed to the area 'adjacent' to it. In my view, this purpose does not fall within section 15 even as amended or within section 17.

The Court of Appeal passed comment upon the judgment of the Honourable Chief Justice J. V. H. Milvain as follows: ${ }^{18}$

An analysis of the reasons of the Learned Chambers Judge discloses that he fully

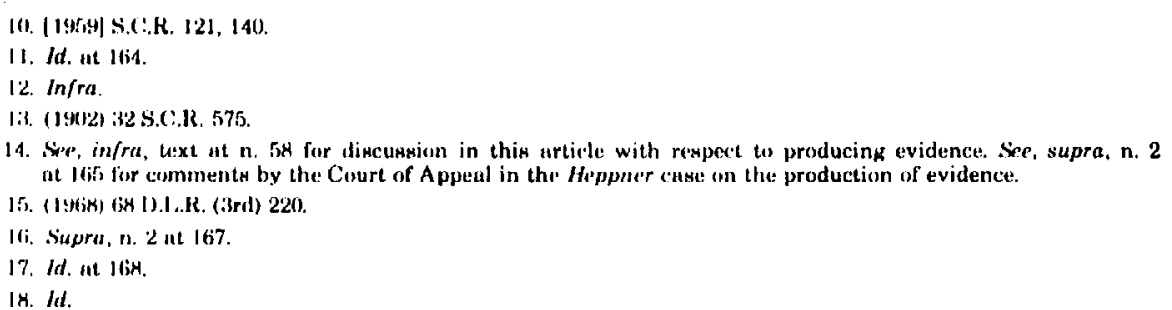


appreciated that 'regulations that can be passed by way of order-in-council must be regulations that are designed to further the purposes of the Act and not for some other purpose' in that he thereafter proceeded to hold that the regulation came 'squarely within the purposes of the Act.' I respectfully suggest that in order to come to this conclusion the Learned Chambers.Judge has opted for the proposition that even if the regulation was passed for a purpose not falling within the powers specifically provided by the terms of the Act as long as it, even in the peripheral fashion, incidentally accomplished the purpose authorized by the Act, in this case, a general advantage to the environment as a whole, it should not be declared invalid. With this proposition I respectfully disagree.

Thus, the Court of Appeal effectively stated that the main purpose of every regulation passed under any act must bear directly upon the purposes of the A.ct and not incidentally on such purposes. It remains to be seen whether the "incidental" and "direct" purposes will receive the same treatment as these terms have received in other areas of the law. ${ }^{19}$

As is the case in many actions involving prerogative writs, the power of the court to strike down legislation is limited. After the court has made its determination, the legislature may then intervene to rectify the situation. ${ }^{20}$ New legislation has now been passed by the legislature of Alberta amending the Department of the Environment Act so that the regulations creating all of the RDA's with the exception of the South Edmonton RDA, are declared valid if they fall within the purposes of the Act (as amended) notwithstanding the reasons for the creation of these $\mathrm{RDA}^{\prime} \mathrm{s}$ at the date of their creation. The Act has been amended to include the creation of transportation and utility corridors as a purpose for Restricted Development Areas. Furthermore, a new regulation has been passed reinstating the South Edmonton RDA. Thus, unless the Alberta Bill of Rights argument referred to above is invoked, or some other technical flaw is found in the legislation, it appears that Heppner has gained very little through his application to the court. ${ }^{21}$

\section{THE LEGACY OF COPITHORNE}

Much has been written about the well-known case of Calgary Power Ltd. v. Copithorne, ${ }^{22}$ a case in which a Minister's order was challenged. In this caise the relevant facts are that the Minister of Agriculture issued an order authorizing Calgary Power to expropriate a portion of Copithorne's land pursuant to the Alberta Water Resources Act, ${ }^{23}$ without holding any hearing or furnishing an opportunity to Copithorne to object to the order. The order recited that the Minister deemed the expropriation necessary for the authorized undertaking of Calgary Power. Copithorne found out about the expropriation when an agent of Calgary Power entered his

19. Reference may be made to well-known constitutional arguments us to the "pith and substance" of legislation. These aryuments deal with aspect, pith, substance, character and purpose of legialation. Reference may be made to Laskin, Canadian Constitutional Law, for further general discusaion on this subject. This goes
beyond the scope of this article.

20. See P. W. Hugg, The Supreme Court of Canada and Administrative Lau', 1949-1971. (1973) 11 Osguode Hall Law Journal 187 ; and for discussions of the particular point raised in the text, namely, the fact that the legislature will ultimutely overrule the courts, ses Angus, supra, $n$. I at 181 .

21. Since the writing of this urticle H new action. Trollenherg v. The Minister of the Environment et al. has been instituted. The action seeks $l_{10}$ impugn the Department of the Finvironment Act and regulations passed thereunder in the basin that it violater the wrovisions of the Alberta Bill of Rights. The action also advances the argument that if there is no violition of the Bill of Rights, the Minister must com penuate Trellenberk as he 'may' da sel under the provisions of the Department of the Environment At the time of writing, the Aturney Cieneral has not yot had the opportunity to argue the mutter before the Supreme Court of Alberta. T'rial Jivision. Undouhtedly this matter will proceed to appeal as well.

22. |j959| S.C.R. 24. For discussion of this case, and particularly how the issue has been subsequently dealt with by the Supreme Court of Cinada, see D. H. Clark. The Supreme Court of Canada the House of Lords, the Sudicial Committee of the Privy Council, and Administrative Law. [1976] Alta. L. Rev. 5, 7.

23 R.S.A. 1943 , c. 65 , s. 75 (2). 
lands and handed him a copy of the order. Copithorne challenged the order and his success is somewhat reminiscent of the success of $\mathrm{Mr}$. Heppner in that at trial the order was sustained, but on appeal to the Alberta Court of Appeal, the ministerial order was declared to be a nullity..$^{24}$

The operative words of the Water Resources $\mathrm{Act}^{25}$ are as follows:

Any licensee for the purpose of the authorized undertaking may with the consent in writing of the Minister may with the consent and writing of the Minister take and acquire by expropriation any land other than Provincial lands or any interest therein which the Minister may deem necessary for the authorized undertaking.

Section $72(2)$ of the Act required the licensee to apply to the Minister for his permission or consent and "the Minister may issue an order authorizing the licenss to expropriate such lands or interest in lands as the Minister by order may designate . . .".

Copithorne challenged the ministerial order, inter alia, on the following grounds:

1. That the powers granted to the Minister as set forth above were quasi-judicial; therefore the Minister was bound to give notice to Copithorne before exercising them and was bound to give Copithorne an opportunity to be heard; and

2. That even if the Minister's powers were administrative, he failed to exercise them in accordance with the requirements of the Act.

On appeal to the Supreme Court of Canada, with respect to the first argument, Martland J. ${ }^{26}$ referred to the case of Nakkuda Ali v. M. F. DeS. Jayaratne. ${ }^{27}$ In this case it was determined that a controller was entitled to revoke a license authorizing a dealer to deal in textiles where the controller had reasonable grounds to believe that the dealer was unfit to be allowed to continue as such. It was held that such revocation was an executive action withdrawing a privilege because the controller believed, and had reasonable grounds to believe that the holder was unfit to retain the license. No procedure was laid down in the applicable statute to give notice, nor was there any right of appeal. It appeared from the Nakkuda Ali case that there was no way of testing whether or not the controller actually had reasonable grounds. The fact that he had to have reasonable grounds was insufficient to oblige him to act judicially.

Martland J. equated the situation in the Copithorne case to the Nakkuda Ali'28 case, and after having considered the case law, stated:29

There is, in my opinion, no justification for saying that the executive decision to make the order can be controlled by the courts by reference to the evidence or lack of evidence at the inquiry which is here relied on ...

Martland J. stated further: ${ }^{3 n}$

... his decision is as a Minister of the Crown and, therefore, a policy decision, taking into account the public interest, and for which he would be answerable only to the legislature...

and: $: 11$

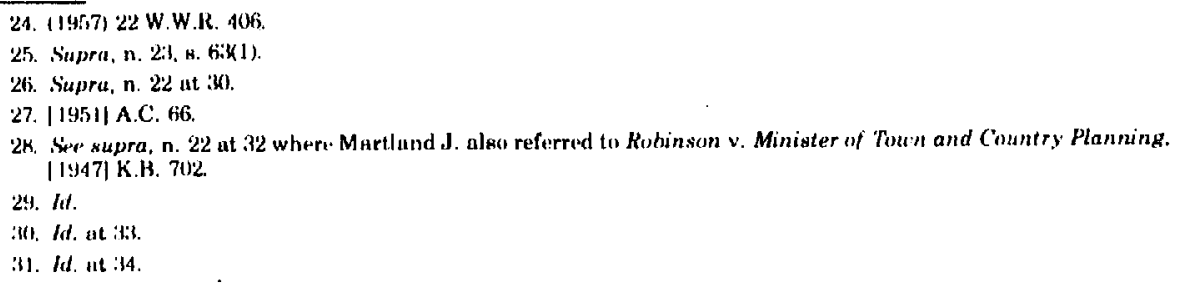


In my view, the powers of the Minister, under the statute in question here, were to make an executive order. His functions were not judicial or quasi-judicial. His decision was an adininistrative one made in accordance with the statutory requirements and to be guided by his own views as to the policy, which in the circumstances, he ought to pursue.

Martland J. deals with the requirement that the Minister can only allow expropriation of lands which are necessary in the following manner. It should be noted that the Minister had written a letter indicating that he had not considered prior to the making of his order whether the taking was necessary. In other words, it was clear that the request by Calgary Power was sufficient for him to make the order.

\section{Pej: Martland J.:32}

The! question as to whether or not the respondent's lands were 'necessary' is not to be determined by the courts in this case. The question is whether the Minister 'deemed' thein to be necessary. In the order which he made he specifically states that he did deem thein necessary for the authorized undertaking of the appellant company. There is no suggestion of bad faith on his part.

and: ${ }^{33}$

I do not construe the letter of August 5, 1955, from the Minister to the respondent as stating the only grounds on which the Minister's decision was reached, or as derronstrating that he has not, prior to the inspection referred to in the last paragraph of it, deemed the lands necessary for the appellant company's undertaking. Rather it indicates that, out of courtesy to the respondent's objections, the Minister had taken additional steps which confirmed his prior decision.

Consequently, the Supreme Court of Canada overruled the Alberta Court of Appeal and upheld the Minister's order. It's the writer's view that this dealt a severe blow limiting the ability to control Ministers from which we have not, in our jurisprudence, yet recovered..$^{34}$

As can be seen from the foregoing discussion of Copithorne, much reliance was placed by the court on the Nakkuda Ali case. In a prior decision, ${ }^{35}$ the House of Lords determined that despite the requirement that the Secretary of State had to have reasonable cause to believe that a person be of hostile origins or associations prior to making a detention order, the Secretary of State could not be called upon to state and justify his grounds for making such an order. It must be remembered that this was a wartime decision but Lord Atkin's dissent is an eloquent protest to unrestrained exercise of power by the ministers: ${ }^{36}$

I viow with apprehension the attitude of judges who on a mere question of construction when face to face with claims involving the liberty of the subject show themselves more executive minded than the executive. ... it has always been one of the pillars of freedom, one of the principals of liberty for which on recent authority we are now fighling, that the judges are no respecters of persons and stand between the subject and any attempted encroachments on his liberty by the executive, alert to see that any coersive action is justified in law. In this case I have listed two arguments which might have! been addressed acceptably to the Court of Kings Bench in the time of Charles I.

I protest, even if I do it alone, against a strained construction put on words with the effect of giving an uncontrolled power of imprisonment to the Minister. To recapitulate. the words have only one meaning. They are used with that meaning in the common law and in statutes. They have never been used in the sense now inputed to them ... after

\footnotetext{
32. Id,

3.1. Id. at is.

51. It is the view of sume writers that although Copithorns has nut been overturned, it has been avoided by the Supreme Cuurt of Canada, particularly in the deciaion of Wiswell v. Metropolitan Corporation of Greater Winnipeg. $|1965|$ S.C.R. 512 , and for commentary on this see Clark, supra, $n$. 22 at 7.

3i. Liurrsidge v. Anderson [1942]A.C. 206; discussed in Wade, Administrative Law, at 8 ?.

3i3. Id.
} 
all this long digcussion the question is whether the words 'if a man has' can mean 'if a man thinks he has'. I am of the opinion that they cannot ...

Although Lord Radcliffe in the Nakkuda Ali case recited Lord Atkin's point of view, he still indicated that the controller did not have to act judicially because the simple requirement that a man must have reasonable grounds for believing something is not enough to require that he arrive at that belief by a course of conduct analgous to the judicial process.

It appears to the writer that Martland J. came far closer to the majority decision in the Liversidge case than he did to the principles which . were stated by Lord Radcliffe in the Nakkuda Ali case, even though that latter case indicated that the controller did not have to act judicially. In fact, it appears from the letter that was written by the Minister in the Copithorne case that the Minister had no reasonable cause to believe that the expropriation was necessary although he did form such a belief sometime after he had made his order. Clearly this is not good enough. Martland J. also indicated that despite the contents of the letter, the bare fact that the Minister would have had an opinion and some information aside from the investigation that was made subsequent to the order, was enough for the Minister to act reasonably. It is the writer's view that even Lord Radcliffe in the Nakkuda Ali case may well have disagreed with this proposition.

In England, the Nakkuda Ali case has subsequently been overruled by the House of Lords in Ridge v. Baldwin. ${ }^{37}$ In that case, a police constable had been tried and acquitted on a criminal charge of conspiracy to obstruct the course of justice. The Brighton Watch Committee, without giving him any notice or offering any opportunity to be heard, had unanimously dismissed the constable from his office. When the dismissal was objected to by the constable's solicitor, the solicitor and the constable appeared at a later meeting at which the Committee confirmed their previous decision but by a vote of 9 against 3 . The constable exhausted his rights of appeal and finally applied to the courts for a declaration that the decision was void because he had not been given notice of the charges against him and had no opportunity to prepare his defence. Pursuant to the legislation, the Watch Committee was empowered to dismiss any constable whom they thought negligent in the discharge of his duty, or otherwise unfit for same. Although this decision does not relate specifically to the control by the courts of a Minister, the decision of Lord Reid is most important because it is the first attack by the House of Lords on the characterization of tribunals as judicial, quasi-judicial, and administrative in nature. The court drew the conclusion that the decision in Nakkuda Ali was based on a serious misapprehension of the older authority and therefore could not be regarded as authoritative.

Lord Reid also stated in his judgment that the Liversidge case was a very peculiar decision of the House of Lords.

Unfortunately, Ridge v. Baldwin has not been followed in Canada, although various peripheral and indirect attacks have been made on Copithorne.

37. [1964] A.(: 41). 


\section{THE DOCTORS HOSPITAL CASE}

Another direct attack on ministerial authority in recent times is the case In Re Doctors Hospital and Minister of Health. ${ }^{38}$ This case was decided in the Ontario High Court, Divisional Court, by a unanimous decision of three judges of the Supreme Court trial division. The case has not been appealed and will likely not be appealed because the parties subsecquently agreed to settle. In the fall of 1975 , the government of the province of Ontario decided to reduce funds expended for hospital care and ir order to do so the Minister of Health selected various hospitals to be closed. The Minister attended at each of the hospitals to advise them of the decision and stated candidly that the decision to close was based upon the need to reduce expenditures. Immediately following the attendance of the Minister on the Doctors Hospital, the Minister wrote to the hospital and an order-in-council was passed to close it.

The Minister found his authority for closing the Doctors Hospital, a public hospital, in the Public Hospitals Act, ${ }^{39}$ which provided that:

Any approval given or deemed to have been given under this Act in respect of a hospital

may be suspended by the Minister or revoked by the Lieutenant-Governor in Council.

The arguments advanced by the Doctors Hospital (and other hospitals also closed by the Minister at approximately the same time) were as followis:

1. That the decision to revoke approval was based upon extraneous matters, specifically, financial considerations that were beyond the pervue of the Public Hospitals Act; and

2. That the decision to revoke had been made by the Lieutenant-Governor in Council without giving the hospitals an opportunity to be heard. 40

Cory J. came to the conclusion that the section of the Act bestowing power in the Lieutenant-Governor in Council to pass an order revoking a hospital approval was never intended to be used as a means of exercising financial control over hospitals since that section of the Act appeared prior to 1937, and funding of hospitals did not commence until the late 1960 's.

Cory $\mathrm{J}$. found, therefore, that the order-in-council was invalid basing his conclusion in law upon the case of In Re Multi-Malls Inc. and Gingerbread Investments Ltd. and the Minister of Transportation and Communication et al. ${ }^{41}$ The only difference between that case and the Hospitals case was the fact that in the Multi-Mall case the Minister was given authority whereas in the Hospitals case the Lieutenant-Governor in Council was given that authority. As Cory J. explains:

Would it make any difference in the Multi-Malls case if instead of the words 'Minister may' the words were the 'Lieutenant-Governor in Council may' or if, in our case, instead of the words 'Lieutenant-Governor in Council may' the words were 'Minister may'? We think not. The issue to be determined is whether the Minister or Lieutenant-Governor in Council is exercising a royal prerogative which is not, per se, subject to court review, or whether the act or acts are done pursuant to the exercise of a statutory power and thus subject to court review. In Border Cities Press Club v. A.G. Ontario, (1955)O.R. 14 at page 19, (1955) I D.L.R. 404 at page 412, Chief Justice Pickup said:

34. (1976) 68 D.L.R. (3rd) 220 .

3. R.S.O. 1970 , c. 378, s. $4(5)$.

4r. It was argued on hehulf of the Atturney General that if a hearing was not required, there was a "bare power" conferred upun the Lieutenant-Gnvernor in Council, and following Australian authorities the LieutenantGovernor in Council could exercise an untrammelled distrution. See supra, n. 38 at $22 \%$

41. $\{1977 \mid$ 14 O.K. (2n.d) 49. This case will subsequently be referred to as the Muti-Malls No. 2 case.

45. Supra, n. iks at $2 \%$ 
In exercising the power referred to, the Lieutenant-Governor in Council was not, in my opinion, exercising a prerogative of the Crown, but a power conferred by statute and such alatutory power can be validly exarcised only by complying with statutory provisions which are, by law, conditions precertent to the exercise of such power.

It has been held that even if made in good faith and with the best of intentions, a departure by a decision making hody from the objects and purposes of the statute purwuant to which it acts is objectionable and subject to review by the courts.

Again, as in the Heppner case, Cory J. resorted to Roncarrelli v. Duplessis ${ }^{43}$ and, in fact, uses the decision of Rand J. from that case to support his conclusions. As Cory J. stated:44

In the absence of clear words in the statute, the discretion granted to the LieutenantGovernor in Council could only be used to pursue the policy and objects of the Act, which are to be determined according to the standard cannons of construction and to that extent, at least, reviewable by the courts. That we take to be the view of Mr. Justice Lacourciere expressed in Multi-Malls at page 18 of his reasons, where he in turn was relying upon and to a certain extent interpreting the speech of Lord Reid in Padfield et al. v. Minister of Agriculture, Fisheries and Food. (1968) A.C. 997. At page 1030 Lord Reid stated:

It is implicit in the argument for the Minister that there are only two possible interpretations of this provision-either he must refer every complaint or he has an unfettered discretion to refuse to refer in any case. I do not think that is right. Parliament must have conferred the discretion with the intention that it should be used to promote the policy and objects of the Act; the policy and objects of the Act must be determined by construing the Act as a whole and construction is always a matter of law for the courts. In a matter of this kind it is not possible to draw a hard and fast line, but if the Minister, by reason of his having misconstrued the Act or for any other reason, so uses his discretion so as to thwart or run counter to the policy and objects of the Act, then our law would be very defective if persons aggrieved were not entitled to the protection of the court. So it is necessary first to consider the Act.

The Divisional Court of Ontario had, in fact, determined from a review of the Act that it was not designed to be used for budgetary restraint.

Interestingly, and somewhat mysteriously, Cory J. goes on to say: ${ }^{45}$

We repeat and emphasize that the court would not and could not, per se, review a decision made pursuant to royal prerogative. However, in the absence of clear words to the contrary, in the Act in question, the court can review the decision of the LieutenantGovernor in Council to ensure that discretion to revoke had only been exercised in pursuance of the objects and policy of the Act.

The court seemed determined to indicate that there are circumstances in which the court cannot review ministerial decisions. What these are had yet to be determined. Furthermore, the court does not indicate whether the order-in-council would be invalid if the Lieutenant-Governor had taken into account considerations other than financial or budgetary restraints, and, indeed does not indicate what its position would be had financial considerations been secondary to other considerations, although a part of the decision.

\section{MINISTERIAL ORDERS AND ZONING REGULATIONS}

There have been several recent decisions, including the Multi-Malls case, on freeze orders and zoning orders which form part of the discussion of this article. Multi-Malls Inc. commenced a series of actions against the Attorney General of Ontario with regard to a Ministerial Zoning Order

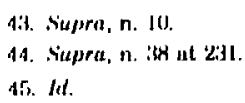


freezing land use and the subsequent exercise of discretion by the Minister of Transportation and Communication refusing land use and highway access permits. Again we find that various government departments have seemingly acted in concert to achieve a common purpoise. The first Multi-Malls case, Re Multi-Malls Inc. and Attorney General of Ontario et al. 46 is a decision of the Ontario High Court of Justice, Divisional Court. Multi-Malls had filed an application for a building permit for a shopping centre to be constructed on lands in the City of Timmons on March 21,1974 . It appears that on March 22 MultiMalls filed certain supplementary information to comply with the relevant zoning and building by-laws but on March 25, 1974, the Minister of Housing passed a regulation pursuant to section 32 of the Planning Act, rrohibiting all commercial development on the Multi-Malls lands and other lands in Timmons formerly comprising the townships of Mount Joy, Tisdale and Whitby. When this Order was made, the official plan for Mount: Joy prohibited the use of the Multi-Malls lands as a shopping centre. However, the official plans for the townships of Tisdale and Whitby designated certain areas within those two townships, and now within Timmons, for commercial development. There was no evidence that the Minister intended to pass such an order prior to the day on which it was actually passed. Lieff $J$. first defined that: ${ }^{47}$

Section 32(4) (of the Planning Act) states clearly that an' order made by the Minister must conform with any official ṕlan in effect. If the order does not conform, there is no power in the court to give the Minister jurisdiction beyond his statutory jurisdiction. In this case, the Minister's order obviously does not conform with the official plans of two of the three townships involved and therefore, taken as a whole, such order is invalid and of no force and effect. Indeed, it is contrary to section 32(4) of the Planning Act.

And:48

Furthermore, the Order was drawn up and put into effect hurriedly. It is blanket in its nature with no attempt to conform with section 32(4) of the Planning Act. We therefore find that ... the entire order is void.

This Multi-Malls case can, however, be distinguished from ministerial power as it is not truly a ministerial power that is being exercised. This is indicaited by Lieff $J .49$

In the present situation, the Minister is given jurisdiction to pass an order exercising any of the powers conferred on municipal council by section 35 of the Planning Act. In no way does section 321 ) of that Act dispense with the requirements of notice of hearing, and it is clear that municipal councils exerciging powers granted to them by section 35 must comply with natural justice. The Minister therefore was under an oblig;ation to give the applicants notice of his intention to pass the order in question and to hear any representations which the applicant desired to make. In this case the Minister acted arbitrarily and with haste and obviously aimed this order at the applicant. This sort of arbitrary action on the part of a government officer cannot be countenanced.

Thus, the Minister was exercising powers which were normally exercised by municipal council. In any event, the ministerial zoning order was declared void.

The second Multi-Malls case (Multi-Malls $\$ 2)^{50}$ involves a shopping centre development. In that case, Multi-Malls held a valid building permit

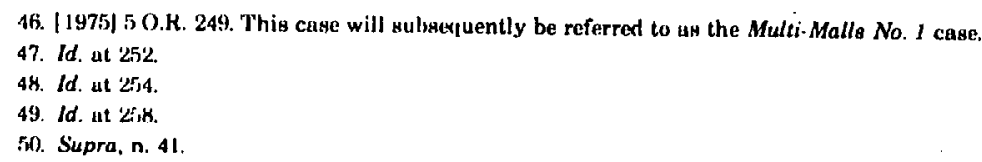


for the construction of a shopping centre in the Township of Norfolks. At the time the application was made, the land on which the proposed shopping centre would be located had been approved by the appropriate Minister. The Minister of Transportation, however, using a discretion conferred upon him under the Public Transportation and Highway Improvement Act, ${ }^{51}$ refused to issue a permit which was required since the shopping centre was within one-half mile of a controlled access highway. The operative words of the ministerial power are found in section 35(11) of the Act as followg:

The Minister may issue permits under this section in such form and upon such terms and conditions as he considers proper and may in his discretion cancel any such permits at any such time.

Multi-Malls claimed that they satisfied all traffic and engineering requirements of the Ministry of Transportation and Communication. The Ontario Court of Appeal found:52

In fact, all requests of the Ministry have been met, involving substantial revision to the building plans, although the Deputy Minister took the vague position that 'no clearly satiafactory solution has yet been produced.'

According to Lacourciere J.A.:53

... considerable pressure was building up on the Minister of Transportation and Communication to deny the road access and entrance permits to the applicant, regardless of the criteria for qualification. . . . The predictable upshot of all this was that the Minister refused to issue the entrance permits, giving as the reason for his refusal that the development 'was in conflict with the official plan'.

Clearly from the correspondence, communications and other evidence before the court, the Minister had not refused the permit because the development was in conflict with the official plan of the municipality. In reality the political pressures brought to bear upon the Minister by the adjoining municipality, and other parties referred by the Court of Appeal, were the true reason for the rejection. The discretion of the Minister is discussed in the same terms as in the Roncarelli case. Per Lacourciere J.A.:54

We are asked to draw the inference that the Legislature wished it to remain clear that the discretion as to cancellation was to remain unfettered; but the discretion is always subject to the requirements of natural justice and to "the control which the judiciary have over the executive, namely that in exercising their powers the latter must act lawfully and that is a matter to be determined by looking at the Act and its scope and object in conferring a discretion upon the Minister . . . per Lord Upjohn in Padfield et al. v. Minister of Agriculture, Fisheries and Food et al,, (1968) A.C. 997 at page 1060.

And again the court distinguishes between royal prerogative and the powers of a minister acting under statutory powers. Per Lacourciere, J.A.:55

While the Minister is undoubtedly a member of the Executive Council, he is, in granting a permit under section $35(11)$, acting in his capacity as the Minister of Transportation and Communications, for the purposes and policies of the Act. He is not then advising the lesislature in a manner of royal prerogative, as in Orpen v. A.G. Ontario (1924) 56 O.L.R. 327, (1925) 2 D.L.R. 366, where he may well not be subject to the supervision or interference of the courts, but merely answerable to the legislature. The courts have always been careful to distinguish between acts done pursuant to the exercise of the

\footnotetext{
51. K.S.(). 1970 , :. 201 .

52. Siupra, n. 41 at 52

5ii) Id. at 5i4.

ia. Id. ut 77 .

5.5. Ll. ut $5 \mathrm{~s}$.
} 
stalutory power--subject to court review-and decisions made under the royal prel:ogative-which are not per se reviewable by the courts: see Border Cities Press Club v. A.G. Ontario (1955) O.R. 14 at page 19, (1955) 1 D.L.R. 404 at page 412 . . .

The court must conclude therefore that: ${ }^{56}$

... the Minister of Transportation and Communication allowed himself to be influenced by extraneous, irrelevant, and collateral considerations which should not have influenced him in the exercise of his discretion to refuse the entrance permit.

The court uses the same reasoning as applied to the Hospitals case and the Heppner appeal. The Act allowed the Minister to achieve certain ends by celtain means in this instance to control traffic by withholding or issuing access permits to highways. The Minister actually used his powers (the means) to achieve an improper end, that of preservation of the inner core of a town against deterioration.

It appears clear from the decision of the Court of Appeal in the MultiMall $\$ 2$ case that the court recognized Copithorne had not yet been overruled by the Supreme Court of Canada. Thus it was necessary to distingzuish the two cases which Lacouriere J.A. manages without difficulty. ${ }^{57}$

This is not a case where the applicant seeks to restrain policy decision of the Minister of the Crown on the grounds that the Minister has failed to act judicially. We are not conierned with the necessity of notice, or with the need for hearing, because the Minister's decision is not challenged for lack of natural justice, as in Calgary Power $L t d$. et a!. v. Copithorne (1959) S.C.R. 16 D.L.R. (2d) 241.

Although the distinction, per se, seems justified, Copithorne also argued that the Minister acted without properly apprising himself of the salient: facts. The court rejected Copithorne's arguments out of hand. However, from reading of the Copithorne case, it does not appear that there was any evidence brought before the court that the Minister in fact considered irrelevant extraneous matters in making his decision to expropriate. The words which appear in the operative section of the Water Resources Act in the Copithorne case are "The Minister may issue an order." As a result a licensee may, with such order, acquire by expropriation lands which "the Minister may deem necessary for the authorized undertaking". The words in the Copithorne case are no broader, certainly, than the words in the Multi-Malls $\# 2$ case, although the history of the legislation is somewhat different. It appears to the writer that it is time for the courts to deal directly with this issue of ministerial discretion rather than skirting it peripherally as has been done to date.

\section{CASES DEALING WITH EXPROPRIATION}

The expropriation of land without proper statutory authority has been considered in a recent decision of the Ontario Court of Appeal, namely LaRusi v. Metropolitan Toronto \& Region Conservation Authority. ${ }^{58}$ In this case the Metropolitan Toronto \& Region Conservation Authority had powers of expropriation only for the purposes of implementing a scheme to consierve, restore or develop natural resources or to prevent floods or pollution. The Conservation Authority had been assembling various lands for the purpose of building a pioneer village and it was clear from

56. Id. at tid

57. Id. ut bil.

58. (1968) 66 I).L.K. (2d) :310. 
the facts that the Conservation Authority wished to acquire LaRush's land solely for the purposes of the pioneer village. The court considered the definition of the words "conservation" and "natural resources" although these words were not defined in the Act. Per Aylesworth J.A.:

It is plain, however, that the only conservation with which the Authority is to be concerned is the conservation of natural resources including control of water to prevent floods or pollution. I am satisfied that 'natural resources' as that expression used throughout the Act and cannot be taken to include farmland as such or an artificially created investment or undertaking such as pioneer village.

Again, the court intervened to impugn the expropriation.

\section{ONUS TO PROVE IMPROPER PURPOSE}

The onus cast upon a person attempting to impugn regulations, ordersin-council or subordinate legislation has been briefly mentioned earlier in this article. This onus is, without doubt, an important consideration for any litigant in these types of proceedings. Not only does the onus place a burden on one party to the litigation, but it also indicates a societal tendency in favour or or against an individual litigant in such proceedings. Apparently, English jurists place greater restraint on the Crown than has yet been the case in Alberta. In the Congreve v. Home Office case, Lord Reid stated:59

It was argued that the Minister is not bound to give any reasons for refusing to refer a complaint to the committee, that if he gives no. reasons his decision cannot be questioned, and that it would be very unfortunate if giving reasons were to put him in a worse position. But I do not agree that a decision cannot be questioned if no reasons are given. If it is the Minister's duty not to act so as to frustrate the policy and objects of the Act, and if it were to appear from all the circumstances of the case that that has been the effect of the Minister's refusal, then it appears to me that the court must be entitled to act.

This passage was cited with approval by Lacourciere J.A. in the MultiMalls $\# 2$ case and even a strict construction seems to imply that in court proceedings the motives of a Minister could be attacked. It is, however, questionable whether a bold allegation of bad faith or improper motive by an applicant could serve to put the Minister on the defensive and require him to produce evidence to the contrary whether by affidavit or otherwise. In fact, if such proceedings were allowed, one can easily see the impairment of the efficient functioning of government. It must be noted that the Congreve case involves a foolish policy decision by a Minister affecting what the public had come to consider one of its most basic rights-that of watching television. Similarly in the Multi-Malls \#2 case, there was ample evidence to disclose improper purpose, regardless of onus.

However, the Alberta Court of Appeal in the Heppner appeal took the exact opposite point of view. Referring to the judgment of C. J. Ford J.A. in County of Newall No. 4 and M.D. of Newall No. 28 v. Standard Gravel and Surfacing Canada Limited, the court determined: ${ }^{00}$

A court when considering the validity of subordinate legislation must proceed on the assumption that such legislation is within the authority conferred by the Act and will not declare it invalid unless there is clear evidence to support such a finding. ${ }^{\text {h1 }}$

69. | $1976 \mid 2$ W.1.H. 291, 305, This care dealt with the revocution by the Home Office of colcur televiaion broadcagt receiving liesences pursuant ta distretionary power in the statute.

(io). Supra, n. 2 al 164.

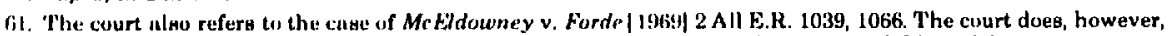
go on to indicate the use of evidence. See the next following heading in the text of this article. 
The Congreve case was not referred to by the appeal court or the parties, although the respondent (the Attorney General of Alberta) argued the question of the burden cast upon the appellant (Heppner) to displace the presumption in favour of the validity of impugned legislation.

It is the writer's view that there must be some presumption in favour of the validity of regulation, orders-in-council and other subordinate legislation required for the functioning of government in today's complex society. However, given the plethora of such subordinate legislation and the broad powers granted to bodies which are not under the direct continisous control of the legislature as a whole, the courts must take a long and careful look at their function as the only lawful control over these administrative bodies and ministers. Presumptions which seemed reasonable in the past may now be too strict.

\title{
VII. EVIDENCE
}

In view of the onus against the applicant in a case such as the Heppner appeal, a person contemplating litigation to impugn legislation must try to marshall whatever evidence is available to disclose, whether directly or indirectly, the motives of an administrative body or minister, or the Lieutenant-Governor in Council for making a decision or promulgating regulations. Investigations must be made into the scope of the enabling legislation intended by the legislature by use of official pronouncements, debates in parliament, the wording of the Act itself and comparison with similar legislation. As in the case of many administrative law decisions, statements by a Minister or other government officials either before or after the fact are most important. Roncarelli, Heppner and the Hospitals case are all good examples of this.

Use: may also be made of correspondence, meetings, telephone conversations, and other material indicating a course of action. In the LaRush case reference is made to minutes of the Executive Committee of the Conservation Authority and a staff report attached thereto, and to a brief prepared by the chief technical officer of the Conservation authority and filed by the Authority with the Minister in support of its application to him for approval. Per Aylesworth J.A.:62

\begin{abstract}
Appillant, as I understand it, contends that none of these documents with the single exception of the appellant's resolution to submit the scheme to the Minister may be looked at and that the evidence of Mr. Higgs called as a witness at the trial by the appellant cannot be looked at to ascertain the purpose of the acquisition of the respondent's lands. The learned trial judge thought he could consider these matters and I emphatically agree. The documents themselves are the appellant's own records of appellant's proceedings and of the action taken by it. The contents of these documents and anything which necessarily follows from the consideration of their contents bears in the most direct way upon the question of the appellant's real purpose. Again, that real purpose properly may be tested in the light of the evidence of Mr. Higgs as to the need or the lack of it to acquire respondent's lands for any purpose of conservation of natural resources...
\end{abstract}

In result, the court determined from the evidence of Higgs, the chief technical adviser of the Conservation Authority, that the lands were not required for flood control or prevention of pollution and their taking could only be justified for the purposes of the pioneer village.

In the Multi-Malls (H2) case, the court found that: 63 
senior members of the Provincial Cabinet, as well as officials of the Town of Tilsenberg, who considered the proposed shopping centre undesirable from a planning point of view, intervened with the Minister of Transportation and Communication, urging him to refuse the necessary approval to the grant of access onto the highway. There is much correspondence in the record to document these interventions, as well as evidence of meetings and delegations.

The court proceeded to describe examples of the type of documentation it referred to, which documentation included letters written from the clerk of the Town of Tilsenberg to the Minister of Transportation and Communications, from the Minister of Housing to the Member of the Provincial Parliament for the area, and from the solicitor for the Town of Tilsenberg to the Plans Administration Branch of the Ministry of Housing. The last communication referred to telephone communications as well, and it is interesting to note that the letter contained the following paragraph:

As I (the solicitor for the T'own of Tilsenberg) have pointed out from time to time on the telephone we believe that the policy of the Province, as it should be expressed by all ministries and not merely one, is to prohibit random development on the edges of the municipality which will have the effect of destroying the economic viability of the central business district of the urban areas . .

.. . we respectfully request that this communication from the Ministry of Treasury, Economics and Inter-Governmental Affairs endorsed by the Ministry of Housing which is within the umbrella of all the senior ministry, should be forwarded to the Ministry of Transportation and Communication.

In this case, we note the inter-governmental co-operation which can indicate a common purpose which may, or may not be, in the public interest but is not authorized by the enabling legislation. The court also considered a traffic engineer's evidence indicating that in his experience the Minister's refusal on the grounds that the proposed development was in conflict with the official plan was entirely unprecedented.

It should be noted that the passage referred to above from the LaRush decision was cited with approval by the Alberta Court of Appeal in the Heppner decision. ${ }^{64}$

The writer recognizes that each case is different and will require an original and unique approach to the evidentiary problems. Some care must be taken to research thoroughly the available evidence, to ensure that nothing is overlooked in the event that the Crown decides not to call any evidence and the presumption against the applicant could prevail. Further, the evidence must be structured in a manner such that the inescapable conclusion of the court shall be that the power has been exercised by the governmental official or board if not in bad faith, at least well beyond the scope of the legislation.

\section{CONCLUSIONS}

With the increasing complexity of government and the accompanying tendency towards government by order-in-council, regulation, and administrative directives, the role of the lawyer becomes simultaneously more important and less effective. A litigant may too often find that unresponsive government agencies or ministers remedy defects in legislation by retrospective legislation as in the Heppner appeal. So long as the courts are unable to make positive orders and are bound to quash or make declaratory judgments, actions may be successful but the end 
result is often unsuccessful. Government by decree has become much too accepted by government itself and the courts must intrude as the last bastion between this type of government and the public. The writer does believe that the government agencies or ministers are acting in good faith in almost all cases and this makes the essential problem more difficult to solve. Firstly, must we sacrifice our historic democratic system which places ultimate power in the hands of the legislature for a systen where the de facto power resides in the hands of government committees and administrative boards? Secondly, we must ask if the courts will ever be effective to control this trend. It does appear to the writer that the legal profession has an obligation to consider these serious issues and to ensure that insofar as it is possible, the ministers are controlled and appreciate their responsibility to exercise their powers in good faith and strictly within the scope of enabling legislation. 